\title{
Is delirium a specific complication of viral acute respiratory distress syndrome?
}

\author{
Markus Jäckel ${ }^{1,2^{*}}$ D, Xavier Bemtgen ${ }^{1,2}$, Tobias Wengenmayer ${ }^{1,2}$, Christoph Bode $^{1,2}$, Paul Marc Biever ${ }^{1,2}$ and \\ Dawid Leander Staudacher ${ }^{1,2}$
}

Keywords: ARDS, Delirium, Intensive care unit, NuDesc, SARS-CoV2

Acute respiratory distress syndrome (ARDS) caused by the novel coronavirus SARS-CoV-2 is associated with a high rate of delirium resulting in encephalopathy, prominent agitation, and confusion [1]. Considering neurotropism of coronaviruses, a direct central nervous system invasion resulting in encephalopathy of SARS-CoV2 is discussed [2, 3]. Recent data reported an enhancement in leptomeningeal spaces and bilateral frontotemporal hypoperfusion in SARS-CoV-2 [1]. Since delirium however might also be caused by the systemic injury in critical illness [4], it remains debatable if the high rate of delirium is specifically associated with SARSCoV-2 or rather a common complication of viral ARDS. We therefore compared delirium in ARDS patients caused by either SARS-CoV-2 or influenza $A$ and $B$ viruses.

We performed a single-center retrospective register analysis including invasive ventilated patients with ARDS and SARS-Cov-2 or influenza infection treated between 2015 and May 2020. We analyzed delirium by NuDesc (nursing delirium screening scale) score and RASS (Richmond agitation and sedation scale) score which are routinely assessed three times a day by especially trained nurses in all patients on our
ICU. The NuDesc score is approved and shows a high sensitivity and specifity [5].

A total of 83 patients with ARDS were identified (44 and 39; with SARS-Cov-2 and influenza, respectively). Thirty-seven (22 and 15) died before extubation and 10 (2 and 8) were transferred with tracheotomia without the possibility of delirium evaluation using a verbal test. We therefore analyzed 36 (20 and 16) patients. Besides of age (patients with SARS-Cov-2 infection were significantly older), groups were homogenous (see Table 1).

Of all analyzed patients $69.4 \%(65.0$ and $75.0 \%$ with SARS-CoV-2 and influenza, respectively) were diagnosed with delirium at any time during the ICU stay. Delirium duration tended to be longer in patients with SARS-CoV-2 $(5.1 \pm 4.3$ days vs. $2.8 \pm 2.4$ days, $p=0.13)$. Delirium severity, defined as maximum of NuDesc score, also tended to be more distinctive in SARS-Cov-2 patients (NuDesc score at maximum: $5.2 \pm 2.6$ vs. $3.7 \pm 1.8, p=0.11)$. The onset of delirium after extubation was similar $(0.50 \pm 1.08$ days vs. $0.8 \pm 1.6$ days). For the delirium presentation, see Fig. 1.

In this registry study of delirium in viral ARDS, we found no statistical significant difference in de-

\footnotetext{
* Correspondence: markus.jaeckel@universitaets-herzzentrum.de

'Department of Cardiology and Angiology I, Faculty of Medicine, Heart Center Freiburg University, University of Freiburg, Hugstetter Strasse 55, 79106 Freiburg, Germany

${ }^{2}$ Department of Medicine III (Interdisciplinary Medical Intensive Care), Medical Center, Faculty of Medicine, University of Freiburg, Freiburg, Germany
} 
Table 1 Characteristics of patients with ARDS caused by SARS-CoV-2 or influenza A/B. For laboratory data, maximum values are shown. $p$ value reported in bold if difference is significant $(p<0.05)$. Data are given as mean \pm standard deviation or number of patients (percent of all patients in group). ${ }^{a}$ Student's $t$ test; ${ }^{b}$ Welch $t$ test, ${ }^{C}$ Chi-square test; ${ }^{d}$ Fisher's exact test

\begin{tabular}{|c|c|c|c|}
\hline & Influenza $(\boldsymbol{N}=16)$ & COVID-19 $(\boldsymbol{N}=20)$ & $p$ \\
\hline Age & $54.31 \pm 12.36$ & $65.48 \pm 10.99$ & $0.007^{2}$ \\
\hline Female & $5(31.3 \%)$ & $4(20.0 \%)$ & $0.470^{d}$ \\
\hline ICU stay (days) & $19.85 \pm 12.09$ & $21.05 \pm 11.77$ & $0.765^{\mathrm{a}}$ \\
\hline Death & $0(0 \%)$ & $2(10.0 \%)$ & $0.492^{d}$ \\
\hline Severe ARDS & $11(68.8 \%)$ & $9(45.0 \%)$ & $0.154^{c}$ \\
\hline Days of invasive ventilation & $18.28 \pm 15.61$ & $15.47 \pm 10.34$ & $0.522^{a}$ \\
\hline TISS 10 & $16.63 \pm 5.73$ & $15.25 \pm 6.77$ & $0.521^{a}$ \\
\hline SAPS 2 & $40.38 \pm 9.88$ & $44.70 \pm 11.13$ & 0.232 \\
\hline Noradrenalin > $1 \mathrm{mg} / \mathrm{h}$ & $8(50.0 \%)$ & $10(50 \%)$ & 1.000 \\
\hline Renal replacement therapy & $4(25.0 \%)$ & $6(30.0 \%)$ & 1.000 \\
\hline Lactat mmol// & $3.35 \pm 1.82$ & $3.07 \pm 2.23$ & 0.369 \\
\hline CRP mg/dl & $302.99 \pm 96.89$ & $257.34 \pm 84.46$ & 0.140 \\
\hline Procalcitonin ng/ml & $59.22 \pm 106.43$ & $17.19 \pm 33.46$ & 0.159 \\
\hline Delirium & $12(75.0 \%)$ & $13(65.0 \%)$ & 0.718 \\
\hline Delirium duration (days) & $2.83 \pm 2.44$ & $5.08 \pm 4.29$ & 0.126 \\
\hline NuDesc score at maximum & $3.67 \pm 1.78$ & $5.15 \pm 2.58$ & 0.109 \\
\hline Delirium onset after extubation (days) & $0.80 \pm 1.55$ & $0.50 \pm 1.08$ & 0.622 \\
\hline
\end{tabular}


A

Delirium subtype in viral ARDS

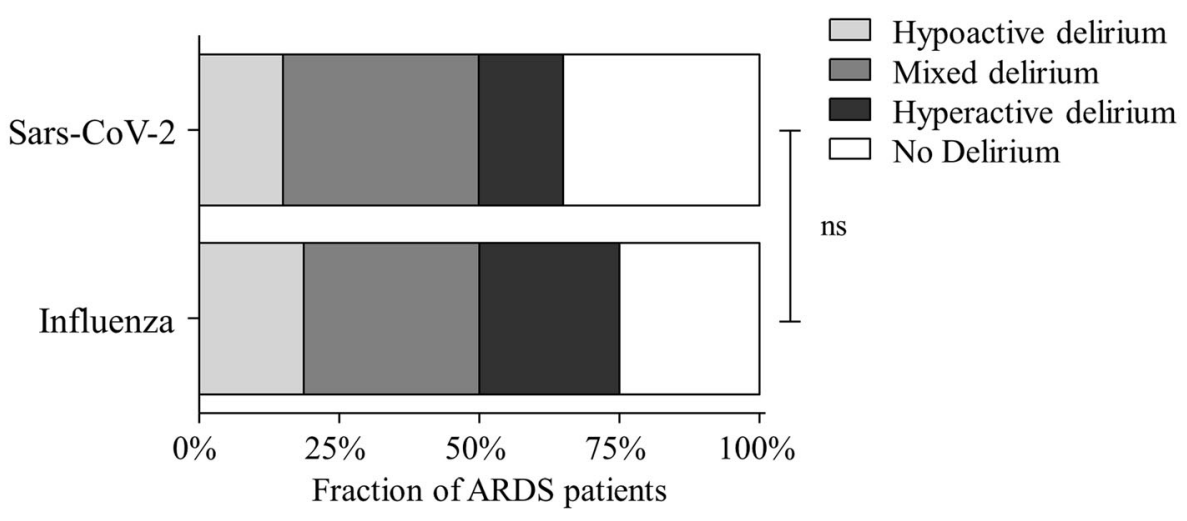

B

Stay on intensive care unit and delirium in viral ARDS

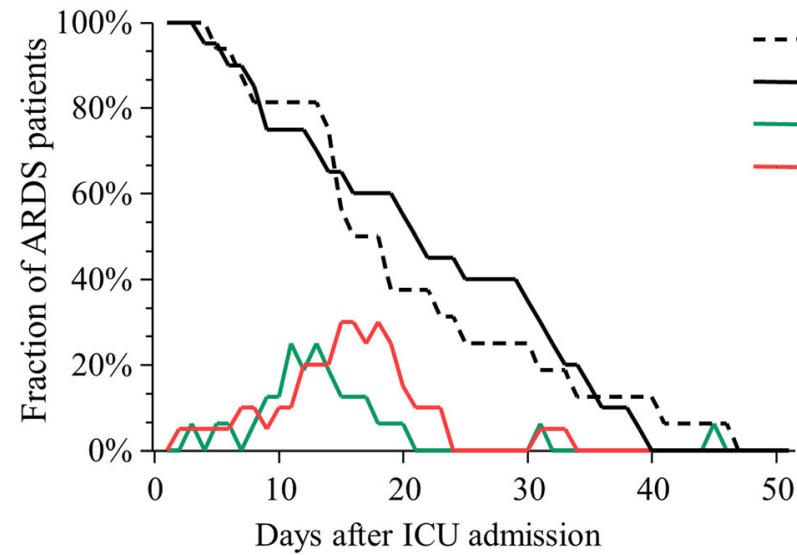

Fig. 1 Delirium presentation and duration. Graph shows delirium distribution of hyperactive/hypoactive/mixed delirium and no delirium shown in percent in patients with ARDS caused by SARS-CoV-2 or influenza A/B (a). Graph shows stay on the intensive care unit and fraction of delirium positive patients shown in percent in patients with ARDS caused by SARS-CoV-2 or influenza A/B (b)

lirium prevalence, intensity, or type of delirium comparing patients with SARS-CoV-2 to those with influenza. We therefore hypothesize that delirium observed in COVID-19 patients has to be considered a complication of ARDS rather than SARSCoV-2 specific. Considering the retrospective nature of data presented here, our results have to be considered hypothesis generating and have to be confirmed in a larger patient collective.

\section{Abbreviations}

ARDS: Acute respiratory distress syndrome; NuDesc: Nursing delirium screening scale; RASS: Richmond agitation and sedation scale;

TISS: Therapeutic Intervention Scoring System; SAPS: Simplified Acute Physiology Score

\section{Authors' contributions}

MJ, PB, and DS carried out the data collection, design, and planning of this study. MJ and DS performed the statistical analysis and drafted the manuscript. All authors participated in the critical discussion of the study and interpretation of data. All authors read and approved the final manuscript.

\section{Funding}

The article processing charge was funded by the Baden-Wuerttemberg Ministry of Science, Research and Art and University of Freiburg in the funding programme Open Access Publishing.

\section{Availability of data and materials}

The datasets used and analyzed during the current study are available from the corresponding author on reasonable request.

Ethics approval and consent to participate

This retrospective study was approved by the ethics committee of the Albert Ludwigs University of Freiburg, file number 387/19.

Consent for publication

Not applicable. 


\section{Competing interests}

The authors declare that they have no competing interests.

Received: 9 June 2020 Accepted: 1 July 2020

Published online: 09 July 2020

\section{References}

1. Helms J, Kremer S, Merdji H, Clere-Jehl R, Schenck M, Kummerlen C,

Collange O, Boulay C, Fafi-Kremer S, Ohana M, Anheim M, Meziani F.

Neurologic features in severe SARS-CoV-2 infection. N Engl J Med. 2020; https://doi.org/10.1056/NEJMc2008597.

2. Arbour N, Day R, Newcombe J, Talbot PJ. Neuroinvasion by human respiratory coronaviruses. J Virol. 2000;74:8913-21 https://doi.org/10.1128/jvi. 74.19.8913-8921.2000.

3. Kotfis K, Williams Roberson S, Wilson JE, Dabrowski W, Pun BT, Ely EW. COVID-19: ICU delirium management during SARS-CoV-2 pandemic. Crit Care. 2020;24:176 https://doi.org/10.1186/s13054-020-02882-x.

4. Larvie M, Lev MH, Hess CP. More on neurologic features in severe SARSCoV-2 infection. N. Engl. J. Med. 2020;382 https://doi.org/10.1056/ NEJMc2015132.

5. Gaudreau J-D, Gagnon P, Harel F, Tremblay A, Roy M-A. Fast, systematic, and continuous delirium assessment in hospitalized patients: the nursing delirium screening scale. J Pain Symptom Manag. 2005;29:368-75 https:// doi.org/10.1016/j.jpainsymman.2004.07.009.

\section{Publisher's Note}

Springer Nature remains neutral with regard to jurisdictional claims in published maps and institutional affiliations.

Ready to submit your research? Choose BMC and benefit from:

- fast, convenient online submission

- thorough peer review by experienced researchers in your field

- rapid publication on acceptance

- support for research data, including large and complex data types

- gold Open Access which fosters wider collaboration and increased citations

- maximum visibility for your research: over $100 \mathrm{M}$ website views per year

At BMC, research is always in progress.

Learn more biomedcentral.com/submissions 